\title{
FAKTOR YANG BERHUBUNGAN DENGAN TINGKAT KECEMASAN PADA PASIEN TUBERKULOSIS PARU YANG MENJALANI PENGOBATAN DI RSUD LABUANG BAJI MAKASSAR
}

\author{
Dewi Sartika.MS
}

\author{
STIKES Amanah Makassar
}

Alamat korespondensi : ( sartikadewy31@gmail.com / 082349606462)

\begin{abstract}
ABSTRAK
Tuberkulosis paru (TB) merupakan masalah kesehatan utama di dunia yang menyebabkan morbilitas pada jutaan orang setiap tahunnya.Tuberkusosis paru masih menjadi beban kesehatan masyarakat di seluruh dunia dan merupakan masalah kesehatan global utama, yang bertanggung jawab terhadap buruknya kesehatan diantara jutaan orang setiap tahun. Penelitian ini bertujuan untuk melihat faktor yang berhubungan dengan tingkat kecemasan pada pasien TB Paru yang menjalani pengobatan TB di RSUD Labuang Baji Makassar. Desain penelitian yang digunakan adalah survey analitik dengan pendekatan Cross-Sectional di mana variabel bebas dan variabel terikatnya akan di kumpulkan secara bersamaan atau dalam waktu yang sama, dengan menggunakan teknik Accidental Sampling, sampel sebanyak 75 responden. Dari hasil uji statistic menggunakan Chi-Square test diperoleh nilai $p=0,002$ dan $p=0,00$ lebih kecil dari nilai $\alpha=0,05$ dengan demikian disimpulkan ada hubungan pengetahuan dan dukungan keluarga dengan tingkat kecemasan pasien di RSUD Labuang Baji Makassar. Sehingga disarankan kepada petugas untuk memberikan pemahaman kepada keluarga dan pasien untuk melakukan terapi pengobatan secara teratur, disamping itu juga diharapkan partisipasi dari keluarga untuk memberikan motivasi dan dorongan kepada pasien untuk menjalani pengobatan secara teratur sehingga pasien cepat sembuh dan merasa tidak cemas.
\end{abstract}

Kata Kunci : Pengetahuan, Dukungan Keluarga, Tingkat Kecemasan, Tuberkulosis Paru

\section{PENDAHULUAN}

TB merupakan penyakit infeksi yang sampai saat ini masih menjadi masalah, baik dalam diagnosis maupun pengobatan (Kurniawan, 2016). Tuberkulosis paru (TB) merupakan masalah kesehatan utama di dunia yang menyebabkan morbilitas pada jutaan orang setiap tahunnya. Berdasarkan laporan WHO tahun 2016, 1.5 juta orang di dunia meninggal karena TB. Tuberkulosis menduduki urutan kedua setelah Human Imunodeficiency Virus (HIV) sebagai penyakit infeksi yang menyebabkan kematian terbanyak pada penduduk dunia (WHO, 2016).

Menurut laporan WHO tahun 2016, Indonesia menempati urutan ke tiga jumlah kasus tuberkulosis setelah India dan Cina dengan jumlah sebesar 700 ribu kasus. Angka kematian masih sama dengan tahun 2011 sebesar 27 per tahun menjadi 185 per 100.000 penduduk di tahun 2012 (WHO,2016).

Khusus di kota Makassar, berdasarkan data yang diperoleh dari Bina Pencegahan Penyakit dan Penyehatan Lingkungan Dinas Kesehatan Kota Makassar, angka penemuan penderita baru TB paru BTA (+) tahun 2014 sebanyak $72,44 \%$ (ditemukan 1.811 penderita dari sebanyak 2.500 sasaran), jumlah ini meningkat dari tahun 2013 dengan jumlah penderita sebanyak 1.324 dari 1.641 sasaran.
Proses penemuan penyakit TB dilakukan oleh pengelola TB masing-masing puskesmas melalui pelacakan / pencarian kasus baru, pelacakan penderita mangkir dan pemeriksaan kontak (Dinkes Prov.Sulsel, 2014).

Berdasarkan pengambilan data awal di RSUD Labuang Baji, didapatkan pasien TB paru yang menjalani pengobatan pada tahun 2017 sebanyak 784 orang sedangkan pada pada tahun 2018 triwulan 563 orang, menurut pihak RSUD Labuang Baji rata-rata pasien TB adalah usia produktif antara 15 sampai 54 tahun.

Tingginya prevalensi TB di Indonesia khusus di daerah Makassar serta resiko yang di timbulkan, menyebabkan beberapa pasien TB mudah mengalami kecemasan. Kecemasan adalah salah satu respon psikologis yang di rasakan pasien dalam menghadapi penyakitnya (Smeltzer \& Bare, 2014).

Kecemasan pada pasien TB berkaitan dengan adanya perasaan khawatir berlebihan terhadap penyakitnya. Pasien diagnisis TB paru, timbul kecemasan perasaan ketakutan dalam dirinya yang dapat berupa ketakutan akan pengobatan, kematian, efek samping obat, menularkan penyakit ke orang lain, kehilangan pekerjaan, ditolak dan didiskriminasikan( Shen et al, 2014). 
Berdasarkan hal tersebut diatas, maka peneliti tertarik untuk melakukan penelitian tentang"faktor yang berhubungan dengan tingkat kecemasan pada pasien TB paru yang menjalani pengobatan TB di RSUD Labuang Baji Makassar".

\section{BAHAN DAN METODE}

Lokasi, Populasi, Sampel

Penelitian ini dilaksanakan di ruang perawatan infeksi paru Baji Ati RSUD Labuang Baji Makassar pada bulan November s/d Desember 2018. Populasi dalam penelitian ini adalah populasi pasien TB paru yang berobat di RSUD Labuang Baji kota Makassar pada tahun 2018 triwulan 563 orang, dengan jumlah sampel penelitian adalah 75 responden.

1. Kriteria Inklusi
a. Pasien TB paru yang berobat di RSUD Labuang Baji Makassar
b. Pasien TB paru usia produktif antara 17 sampai 80 tahun
c. Bersedia menjadi responden
d. Bisa membaca dan menulis

2. Kriteria Eksklusi
a. Pasien TB paru yang tidak berobat di RSUD Labuang Baji Makassar
b. Tidak bersedia menjadi responden
c. Tidak bisa membaca dan menulis

\section{Pengumpulan Data}

1. Data primer, kuesioner merupakan daftar pertanyaan yang di susun secara tertulis dalam rangka pengumpulan data Sedangkan observasi adalah peneliti mengobservasi dan mencatat apa yang di lihat dengan suatu perencanaan (Nursalam, Siti Pariani,2010).

2. Data sekunder, data yang di ambil dari dinas kesehatan, RSUD Labuang Baji, jurnal, buku dan internet.

\section{Pengolahan Data}

1. Editing, setelah data terkumpul maka dilakukan pemeriksaan kelengkapan data, kesinambungan dan keseragaman data.

2. Coding, dilakukan untuk mempermudah pengolahan data yaitu memberikan simbol-simbol dari setiap jawaban responden.

3. Tabulasi, mengelompokan data dalam bentuk tabel yaitu hubungan antara variabel dependen dan independen.

Analisa Data

1. Analisa Univariat Membuat tabel distribusi frekuensi dan presentase dari masing-masing variable.

2. Analisa bivariat
Analisa digunakan untuk mengetahui hubungan antara variabel independen mengunakan uji statistic alternatif Kolmogorof-Smirnov dengan tingkat kemaknaan $\alpha=0,1$. Setelah uji hipotesis dilakukan, dengan taraf kesalahan $1 \%$.

\section{HASIL PENELITIAN}

1. Analisis Univariat Tabel 1 Karakteristik Responden (N=75)

\begin{tabular}{|c|c|c|}
\hline Karakteristik & \multicolumn{2}{|c|}{ Total } \\
\cline { 2 - 3 } Responden & $\mathrm{n}$ & $\%$ \\
\hline Umur & & \\
Beresiko & 38 & 50,7 \\
Tidak Beresiko & 37 & 49,3 \\
\hline Jenis Kelamin & & \\
Laki-laki & 40 & 53,3 \\
Perempuan & 35 & 46,7 \\
\hline Pekerjaan & & \\
IRT & 27 & 36,0 \\
Swasta & 12 & 16,0 \\
PNS & 11 & 14,7 \\
Mahasiswa & 6 & 8,0 \\
Petani & 2 & 2,7 \\
Pedagang & 10 & 13,3 \\
Tukang Becak & 7 & 9,3 \\
\hline
\end{tabular}

Berdasarkan table 1 menunjukkan bahwa mayoritas responden 38 orang $(50,7 \%)$ umur beresiko dan yang paling sedikit adalah umur tidak beresiko sebanyak 37 orang (49,3\%). Kelompok usia responden, mayoritas responden 40 orang $(53,3 \%)$ jenis kelamin laki-laki dan yang perempuan sebanyak 35 orang $(46,7 \%)$. tingkat Pekerjaan, mayoritas responden 27 orang $(36,0 \%)$ berstatus pekerjaan lbu rumah tangga dan yang paling sedikit adalah status pekerjaan petani sebanyak 2 orang $(2,7 \%)$.

2. Analisis Bivariat

Tabel 2 Analisis Hubungan Pengetahuan dengan Tingkat Kecemasan Pasien Di RSUD Labuang Baji Makassar.

\begin{tabular}{|c|c|c|c|c|c|c|}
\hline Duku & \multicolumn{5}{|c|}{ Tingkat Kecemasan } \\
\cline { 2 - 7 } ngan \\
Keluarg & Ringan & \multicolumn{2}{|c|}{ Sedang } & \multicolumn{1}{c|}{ Total } \\
\cline { 2 - 7 } a & $\mathrm{n}$ & $\%$ & $\mathrm{n}$ & $\%$ & $\mathrm{n}$ & $\%$ \\
\hline Baik & 17 & 63,0 & 10 & 20,8 & 27 & 36,0 \\
Kurang & 10 & 37,0 & 38 & 79,2 & 48 & 64,0 \\
\hline Jumlah & 27 & 100 & 48 & 100 & 75 & 100 \\
\hline \multicolumn{6}{|c|}{$P=0,00$} \\
\hline
\end{tabular}

Berdasarkan tabel 2 di atas menunjukkan bahwa dari 39 responden yang pengetahuan cukup, terdapat 21 orang $(77,8 \%)$ mengalami kecemasan ringan, dan 18 orang $(37,5 \%)$ mengalami 
kecemasan sedang. Sedangkan dari 36 responden yang pengetahuan kurang, 30 orang $(62,5 \%)$ mengalami kecemasan sedang. Berdasarkan hasil uji statistic menggunakan uji Chi-Square Tests diperoleh nilai $p=0,002$ lebih kecil dari nilai $\alpha=0,05$ dengan demikian disimpulkan bahwa terdapat hubungan pengetahuan dengan tingkat kecemasan pasien di RSUD Labuang Baji Makassar.

Tabel 3 Analisis Hubungan Antara Dukungan Keluarga dengan Tingkat Kecemasan Pasien Di RSUD Labuang Baji Makassar.

\begin{tabular}{|c|c|c|c|c|c|c|}
\hline \multirow{3}{*}{$\begin{array}{l}\text { Penge } \\
\text { ta } \\
\text { huan }\end{array}$} & \multicolumn{6}{|c|}{ Tingkat Kecemasan } \\
\hline & \multicolumn{2}{|c|}{ Ringan } & \multicolumn{2}{|c|}{ Sedang } & \multicolumn{2}{|c|}{ Total } \\
\hline & $n$ & $\%$ & $\mathrm{n}$ & $\%$ & $\mathrm{n}$ & $\%$ \\
\hline Cukup & 21 & 77,8 & 18 & 37,5 & 39 & 52,0 \\
\hline Kurang & 6 & 22,2 & 30 & 62,5 & 36 & 48,0 \\
\hline Jumlah & 27 & $\begin{array}{c}100, \\
0\end{array}$ & 48 & 100 & 75 & 100 \\
\hline
\end{tabular}

Berdasarkan tabel 3 di atas menunjukkan bahwa dari 27 responden yang dukungan keluarga baik, sebanyak 17 orang $(100,0 \%)$ mengalami kecemasan ringan dan 10 Orang (20,8\%) mengalami kecemasan sedang. Sedangkan dari 48 responden yang dukungan keluarga kurang, sebanyak 38 orang $(79,2 \%)$ mengalami kecemasan sedang. Berdasarkan hasil uji statistic menggunakan uji Chi-Square Tests diperoleh nilai $p=0,00$ lebih kecil dari nilai $\alpha=0,05$ dengan demikian disimpulkan bahwa terdapat hubungan dukungan keluarga dengan tingkat kecemasan pasien di RSUD Labuang Baji Makassar.

\section{PEMBAHASAN}

1. Hubungan Kecemasan

Pengetahuan dengan

Hasil analisa univariat menunjukkan bahwa sebagian besar 39 orang (52,0\%) responden memiliki pengetahuan cukup, dan yang memiliki pengetahuan kurang sebanyak 36 orang $(48,0 \%)$. Demikian pula dengan hasil analisa bivariat menunjukkan bahwa dari 39 responden yang pengetahuan cukup, sebanyak 21 orang $(100,0 \%)$ mengalami kecemasan ringan dan 18 orang $(37,5 \%)$ mengalami kecemasan sedang. Sedangkan dari 17 responden yang pengetahuan kurang, sebanyak 30 orang $(62,5 \%)$ mengalami kecemasan sedang.

Sedangkan hasil pengamatan dan wawancara yang didapatkan pada saat pengambilan data adalah bahwa hampir rata-rata responden yang berpengetahuan kurang mengalami kecemasan sedang dibandingkan dengan pengetahuan cukup yang ditandai dengan ungkapan responden bahwa dia merasa sangat cemas tentang pengobatan yang dijalaninya, responden sering meminta untuk mengulangi pertanyaan yang diberikan, sering bingung terhadap penjelasan yang diberikan karena kurang dimengerti, wajah pucat, dan sedikit dari responden biasanya berkeringat. Sedangkan yang berpengetahuan cukup hanya memperlihatkan tanda-tanda kecemasan yang sedikit. Hal ini dapat dilihat pada saat responden diwawancarai tentang bagaimana keadaannya, sebagian besar mereka mengatakan bahwa baikbaik saja. karena responden mengatakan bahwa dengan pengobatan yang mereka jalani merupakan usaha untuk cepat sembuh dari sakit. Hal ini sejalan dengan teori Rothrock J, 2000 yang menyatakan bahwa Pengetahuan dapat membantu pasien mencapai respon yang optimal tentang respon fisiologis dan psikologis terhadap intervensi pengobatan. Dengan adanya pengetahuan, pasien dapat memuat strategi koping, mengubah prilaku, mempelajari tehnik baru, mengendalikan respon emosi dan bersiap terhadap dampak stress.

Hasil uji statistic Chi-Square Tests di peroleh nilai $p=0,002$ atau $<0,05$, artinya terdapat hubungan yang signifikan antara Pengetahuan dengan tingkat kecemasan pasien TB paru yang menjalani pengobatan di RSUD Labuang Baji Makassar.

Hasil ini sejalan dengan penelitian yang dilakukan Suci Rahayu Ningsih (2010) dengan judul "Faktor-faktor yang berhubungan dengan kecemasan anggota keluarga pada penularan TB paru diwilayah kerja Puskesmas Mopuya dengan hasil $p=0,000(p<0,005)$.

Berdasarkan hasil penelitian yang dilakukan Suci Rahayu Ningsih (2010) dan teori-teori yang dikemukakan, maka dapat dikatakan bahwa kecemasan yang dialami pasien TB yang menjalani pengobatan lebih banyak yang memiliki pengetahuan cukup daripada yang memiliki pengetahuan kurang. Hal ini terjadi karena pasien yang memiliki pengetahuan yang cukup tentang keuntungan dan kerugian pengobatan tersebut sehingga mereka selalu merasa was-was tentang bagaimana yang selanjutnya terjadi selama pengobatan dan pasien yang memiliki Pengetahuan yang kurang memperlihatkan mengalami 
kecemasan Berat hal ini dikarenakan pasien tersebut belum mampu memahami dan menganalisis semua pengetahuan yang diberikan tentang keuntungan maupun kerugian pengobatan tersebut.

2. Hubungan Dukungan Keluarga dengan Kecemasan

Hasil analisa univariat menunjukkan bahwa sebagian besar 48 orang $(64,0 \%)$ responden memiliki dukungan keluarga kurang, dan yang memiliki dukungan keluarga baik sebanyak 27 orang $(36,0 \%)$. Demikian pula dengan hasil analisa bivariat menunjukkan bahwa dari 48 responden yang dukungan keluarga kurang, sebanyak 38 orang $(79,2 \%)$ mengalami kecemasan sedang. Sedangkan dari 27 responden yang dukungan keluarga baik, sebanyak 17 orang $(100,0 \%)$ mengalami kecemasan ringan dan 10 orang $(20,8 \%)$ mengalami kecemasan sedang.

Berdasarkan hasil penelitian dengan menggunakan uji Chi-Square Tests di peroleh nilai $p=0,00<0,05$, artinya terdapat hubungan yang signifikan antara dukungan keluarga dengan tingkat kecemasan pasien TB paru yang menjalani pengobatan di RSUD Labuang Baji Makassar.

Dukungan yang diberikan keluarga untuk mengurangi kecemasan pasien itu sendiri adalah dukungan informasional, dimana keluarga memberikan nasehat, saran, dukungan jasmani maupun rohani. Dukungan emosional juga diberikan keluarga, yang meliputi dukungan yang diwujudkan dalam bentuk afeksi, adanya kepercayaan, perhatian, mendengarkan dan didengarkan. Dukungan lainnya adalah dukungan penilaian dan dukungan instrumental (Friedman, 2008).

Responden yang mempunyai dukungan keluarga baik yang mendominasi ini karena mereka atau keluarga tersebut dapat menjelaskan tentang pentingnya meminum obat secara teratur, keluarga menyarankan responden untuk rutin control di pelayanan kesehatan, keluarga mendukung responden untuk menjalani pengobatan sampai sembuh, dan keluarga menunjukan wajah yang menyenangkan saat membantu responden. Sebab lain yang menyebabkan responden mempunyai dukungan keluarga baik adalah keluarga mendengarkan keluhan yang dirasakan serta keluarga tidak memarahi saat responden bosan menjalani pengobatan. Hal ini menurut Rensi (2010), mengatakan bahwa individu menafsirkan setiap orang lain melakukan sesuatu hal terhadap dirinya berupa informasi maupun nasehat secara verbal atau nonverbal, memberikan sarana prasarana, perhatian emosional yang akan membuat individu merasa diperhatikan. Adapun dukungan keluarga yang tergolong kurang pada responden disebabkan oleh sebagian besar responden menganggap bahwa keluarga tidak memberikan saran atau anjuran pengobatan dari pelayanan kesehatan, keluarga tidak meminta pendapat responden terdahulu dalam rencana pengobatan, keluarga menegur responden saat ada keperluan saja, dan keluarga tidak menanyakan keluhan yang responden rasakan.

Maka dari itu Peneliti berasumsi bahwa kondisi yang dialami pasien TB Paru dapat menimbulkan kecemasan pada diri pasien karena sering dianggap gejala yang dialaminya merupakan suatu tanda yang berat dari penyakitnya. Selain itu juga dukungan keluarga sangat dibutuhkan oleh pasien dimana dalam semua tahap, dukungan sosial keluarga menjadikan keluarga mampu berfungsi dengan berbagai kepandaian dan akal, sehingga akan meningkatkan.

\section{KESIMPULAN}

1. Ada hubungan pengetahuan dengan tingkat kecemasan di RSUD Labuang Baji Makassar.

2. Ada hubungan dukungan keluarga dengan tingkat kecemasan di RSUD Labuang Baji Makassar.

\section{SARAN}

1. Bagi Rumah Sakit, diharapkan hasil penelitian ini dapat menjadi bahan petimbangan dalam meningkatkan pelayanan melalui kebijakan untuk mengijinkan keluarga memberikan dukungan psikologis yang berdampak pada penurunan angka kematian akibat kecemasan.

2. Bagi Responden, diharapkan kepada keluarga pasien untuk memberikan dukungan kepada pasien dalam menjaani pengobatan serta diharapkan kepada pasien untuk melakukan pengobatan secara teratur untuk menghindari kekambuhan dari penyakitnya.

3. Bagi Peneliti Lain, diharapkan peneliti selanjutnya melakukan studi tentang faktor lain yang mempengaruhi tingkat kecemasan pasien TB paru yang menjalani pengobatan. 


\section{DAFTAR PUSTAKA}

Dinkes Prov. Sulsel, (2014). Rekapitulasi Laporan Hasil P2 TB Paru melalui Tribulan TB. 07, Dinkes Prov. Sulsel, Makassar

Harrison (2014). Prinsif-prinsif Ilmu Penyakit Dalam, Penerbit Buku Kedokteran EGC. Jakarta

Kurniawan, (2015). Hubungan Konversi Sputum dengan Status Gizi Pasien Tuberkulosis yang telah Menjalani Pengobatan Fase Intensif.http://scholar.unand.ac.id/3766/2/BAB\%201.pdf

Nursalam, (2010). Metodelogi penelitian kesehatan. Rineka Cipta. Jakarta

Rensi, (2010). Dukungan Sosial, Konsep Diri, dan Prestasi belajar siswa SMP Kristen YSKI Semarang. Jurnal Psikologi, Volume 3 no 2.

Shen Et al. (2014). Pengaruh cognitive dan Acceptance and Commitment Therapy terhadap Ansietas, Depresi Klien Tuberkulosis. Jurnal Ilmiah Keperawatan. Vol 9. No 1 Surabaya

Smeltzer \& Bare, (2014), Buku Ajar Keperawatan Medikal Bedah Vol 3. Edisi 8 EGC, jakarta

Widoyono. (2013). Penyakit Tropis;Epidemologi, Penularan, Pencegahan \& Pemberantasannya. Penerbit Erlangga. Jakarta.

World Health Organization (WHO). (2015). Hubungan Konversi Sputum dengan Status Gizi Pasien Tuberkulosis yang telah Menjalani Pengobatan Fase Intensif.http://scholar.unand.ac.id/3766/2/BAB\%201.pdf 